Ann. Biol. anim. Bioch. Biophys., 1976, 16 (2), 177-194.

\title{
IMMUNOCYTOLOGICAL EVIDENCE OF LH-RF IN HYPOTHALAMUS AND MEDIAN EMINENCE : A REVIEW
}

\author{
M.-P. DUBOIS \\ Laboratoire de Physiologie de la Reproduction, \\ Centre de Recherches de Tours, I. N.R. A., \\ Nouzilly, 37380 Monnaie (France)
}

\section{SUMMARY}

I. The author reviews reports about the immunocytological demonstration of LH-RF in the hypothalamus and describes the materials and methods used by different groups of workers.

2. The different authors are in agreement about the localization of LH-RF axons and axonal endings.

The hypothalamo-infundibular pathway, which is the principal LH-RF neurosecretory pathway, and the accessory extra-hypophyseal pathways in guinea-pig, dog, cat and primates, and the distribution of LH-RF in the median eminence of ram, birds (cock, duck) and amphibians (toad, xenopus, triton) are described.

3. Data concerning the identification of LH-RF producing perykaria are conflicting :

a) In mice, the results of Zimmerman et al. (I974) are not considered specific ;

b) In mice and rat, NAIK's data do not seem convincing ;

c) In mammals (guinea-pig, dog and primates : BARRY et al., LEONARDELli et al.) and in amphibians (DOERR-SchotT and DuboIs) the results have not yet been confirmed. According to the latter, LH-RF perykaria are localized either in the mediobasal hypothalamus (primates) or in a region extending between the preoptic area and the caudal part of the tuber cinereum (guinea-pig, dog, cat) or in the posterior nuclei of the septum (xenopus, buffo).

The differences these authors observed by immunocytology in the hypothalamic perykaria of primates and other mammals agrees well with the differences in gonadotrophin release soon after deafferentation of the mediobasal hypothalamus in these two groups of mammals.

Criticisms of this type of identification of LH-RF perikarya are discussed.

The existence of "free " LH-RF which is not visualized as opposed to " bound " LH-RF demonstrated by immunohistochemistry is evoked to explain negative results obtained in attempts to demonstrate immunoreactive LH-RF perykaria in such species as the rat. 


\title{
ABRÉVIATIONS
}

\author{
$\mathrm{Ab}:$ Antibody \\ IgG : Immunoglobulin $G$ \\ LH-RF : Luteinizing Hormone Releasing Factor \\ BSA : Bovine Serum Albumin \\ HSA : Human Serum Albumin
}

\section{INTRODUCTION}

At the end of 1972 , an antigen immunologically related to LH-RF was demonstrated for the first time by immunofluorescence in axonal endings of the Median Eminence (M.E.). This study on the guinea-pig was made in our laboratory by LEONARDELLI et al. (I973).

At the beginning of I973 BARRy et al., using the same method, observed reacting cells in the hypothalamus of castrated male guinea pigs given colchicine by intracisternal way.

During the years I973-I974, these authors published seriate reports describing this entity of pericaryons and nervous fibres in the guinea-pig in various physiological or experimental conditions. Recently, the localisation of LH-RF in other species (dog, cat, primates) has been reported (BARRY and DuboIs, I973 $a, b$; BARRY and DuboIs, I974 $a, b, c, d, e, f$; BARRY and DuboIs, I975; BARRY et al., I973, I974, I975; LEONARDELLI and DUBOIS, I974 $a, b$; LEONARDEL, $e t$ al., 1974).

Concurrently, Mazucca and Dubors (r974) in guinea-pig, Kordon et al. (1974), KING et al. (I974) in rat, BAKER et al. (I974) in guinea-pig and rat, AlPERT et al. (1975), SETALO et al. (I975) in rat, using immunoenzymohistochemistry, obtained identical results on the M.E. but were unsuccessful in identifying hypothalamic pericaryons synthetizing L,H-RF. The report of ZIMmERMAN et al. (r974) using mice was strongly criticized by SETALO et al. (1975).

Preliminary results in cattle, sheep and pig were given by the author (DuBors, I973 a), who described the exact arrangement of LH-RF in the M.E. of ram (DuBoIs, I973 b). In 1974, relations between LH-RF, SRIF (ALPERI et al., loc. cit.) and between LH-RF, SRIF and neurophysin (DUBoIs and BARRY, I974) in the same area were also reported.

L.H-RF was localized in the M.E. in birds by de REVIERS and Dubors (I974) studying cock and CALAS et al. (I973) studying duck.

In the lower vertebrates, DOERR-SchotT and DuboIs (1974, 1975 $a, b)$ reported the presence of LH-RF in the M.E. and the pars nervosa of toad, and recently localized immunoreactive cells in the encephalon of the same species. A complete distribution of the LH-RF system (pericaryons and axonal fibres) in the Xenopus has since been given; it seemed to be a very good model for this study. Immunoreactive axonal endings have also been seen in neotenic triton (GABRION and DUBOIs, unpublished). 
Pelietier et al. (r974) in rat and Calas et al. (r974) in duck demonstrated reacting axons in the M.E. by ultrastructural immunocytoenzymology.

Recently, NAÏk (I975a,b) reported immunoreactive LH-RF neurons (pericaryons and axons) in the hypothalamus of rat and mice using immunocytological methods at structural and ultrastructural levels.

\section{MATERIALS AND METHODS}

$$
\text { I. - Antisera }
$$

Antisera were usually obtained from rabbits. Their preparation differed with the authors (table I). As a general rule, LH-RF (or a residue with terminal free amino-group) was linked to a protein carrier (HSA, Thyroglobulin, IgG) using glutaraldehyde, toluene diisocyanate, bis diazoted benzidine of carbodiimide.

The immunogen complex was emulsified with Freund's complete adjuvant and injected to rabbits repeatedly.

Antisera to be used were saturated with the protein carrier in order to retain only the anti LH-RF Ab.

TABLE I

Antiseva used in immunocytological studies of LH-RF

\begin{tabular}{|c|c|c|}
\hline Origin & Reports & Immunogen \\
\hline 1. Dubors M. P. & $\begin{array}{l}\text { BARRY et al. } \\
\text { LEONARDELLI et al. } \\
\text { DOERR-SCHOTT et al. } \\
\text { MAZUCCA et al. } \\
\text { de REVIERS } \text { et al. }\end{array}$ & $\begin{array}{l}\text { LH-RF/HSA/glutaraldehyde } \\
\text { LH-RF/HSA/Toluene diisocyanate }\end{array}$ \\
\hline $\begin{array}{l}\text { 2. Kerdelhue B. } \\
\text { (Kerdelhue et al., 1973) }\end{array}$ & $\begin{array}{l}\text { KORDON et al. } \\
\text { CALAS et al. }\end{array}$ & LH-RF/guinea-pig Ig./glutaraldéhyde \\
\hline $\begin{array}{l}\text { 3. NISWENDER G. } \\
\text { (NETT et al., 1973) }\end{array}$ & ZIMMERMAN et al. & $\begin{array}{c}\text { Tyrosine and/or histidine residue of } \\
\text { LH-RF/BSA/Bisdiazoted Benzidine }\end{array}$ \\
\hline $\begin{array}{l}\text { 4. Arimura A. } \\
\text { (ARIMURA et al., 1973, 1975) }\end{array}$ & $\begin{array}{l}\text { Setalo et al. } \\
\text { PeLletier et al. }\end{array}$ & Glycine $^{10}$ LH-RF/BSA/carbodiimide \\
\hline $\begin{array}{l}\text { 5. Dermody W. C. } \\
\text { (Dermody et al., 1973) }\end{array}$ & BAKER et al. & LH-RF \\
\hline 6. Hirsch M. & NaIK & Not specified (unpublished) \\
\hline $\begin{array}{l}\text { 3. Niswender G. } \\
\text { 4. ARIMURA A. }\end{array}$ & KING et al. & Cf. 3., 4. \\
\hline
\end{tabular}

$$
\text { 2. - Material }
$$

Species studied are given in table 2. 
TABLE 2

Species studied by various authors

\begin{tabular}{|c|c|c|}
\hline \multicolumn{3}{|c|}{ I. - Mammalians } \\
\hline Guinea-pig & $\begin{array}{l}\text { BARRY et al. }(1) \\
\text { BARRY et al. }(2) \\
\text { BARRY and DUBOIS } \\
\text { BARRY and DUBOIS } \\
\text { LEONARDELLI et al. } \\
\text { LEONARDELLI and DuBoIs } \\
\text { LEONARDELLI et al. } \\
\text { MAZUCCA and DUBOIS } \\
\text { BAKER et al. }\end{array}$ & $\begin{array}{l}1973 \\
1973 \\
1973 a, b \\
1974 a, b \\
c, d, e, f \\
1973 \\
1974 a, b \\
1974 \\
1974 \\
1974\end{array}$ \\
\hline Hamster & LEONARDELLI et al. & 1973 \\
\hline Rat & $\begin{array}{l}\text { BARRY alld DUBOIS } \\
\text { LEONARDELLI et al. } \\
\text { BAKER et al. } \\
\text { KING et al. } \\
\text { KORDON et al. } \\
\text { PELLETIER } \text { et al. } \\
\text { ALPERT et al. } \\
\text { NAIK } \\
\text { SETALO et al. }\end{array}$ & $\begin{array}{l}1973 a \\
1973 \\
1974 \\
1974 \\
1974 \\
1974 \\
1975 \\
1975 a, b \\
1975\end{array}$ \\
\hline Mouse & $\begin{array}{l}\text { ALPERT } e t a l . \\
\text { ZIMMERMAN } e t \text { al. } \\
\text { NAÏK }\end{array}$ & $\begin{array}{l}1975 \\
1975 \\
1975 a, b\end{array}$ \\
\hline Cat, dog & BARRY and DUBOIS & 1975 \\
\hline $\begin{array}{r}\text { Cattle (sheep, ox, } \\
\text { pig) }\end{array}$ & $\begin{array}{l}\text { DuBoIs M. P. } \\
\text { DuBoIs and BARRY }\end{array}$ & $\begin{array}{l}1973 \\
1974\end{array}$ \\
\hline Primates & BARRY et al. & 1975 \\
\hline \multicolumn{3}{|c|}{ II. - Birds } \\
\hline Duck & $\begin{array}{l}\text { CALAs et al. } \\
\text { CALAs et al. }\end{array}$ & $\begin{array}{l}1973 \\
1974\end{array}$ \\
\hline Cock & de Reviers and Dubois & 1974 \\
\hline \multicolumn{3}{|c|}{ III. - Amphibians } \\
\hline Toad & $\begin{array}{l}\text { DoERR-SchotT and DUBoIs } \\
\text { DoERR-SchotT and DuboIs }\end{array}$ & $\begin{array}{l}1974 \\
1975\end{array}$ \\
\hline Xenopus & DOERR-SchotT and DUBOIS & $1975 b$ \\
\hline
\end{tabular}

Preparation of samples.

a) Photonic microscopy.

Tissues were fixed by various ways and embedded into paraffin (or polywax Iooo) or frozen and cut in cryostat for the immunocytological studies.

b) Electronic microscopy.

After fixation, tissue was embedded in araldite and serial fine sections mounted on grids were directly treated by immunocytological methods according to Moriarty and Halmi (I972) ; 


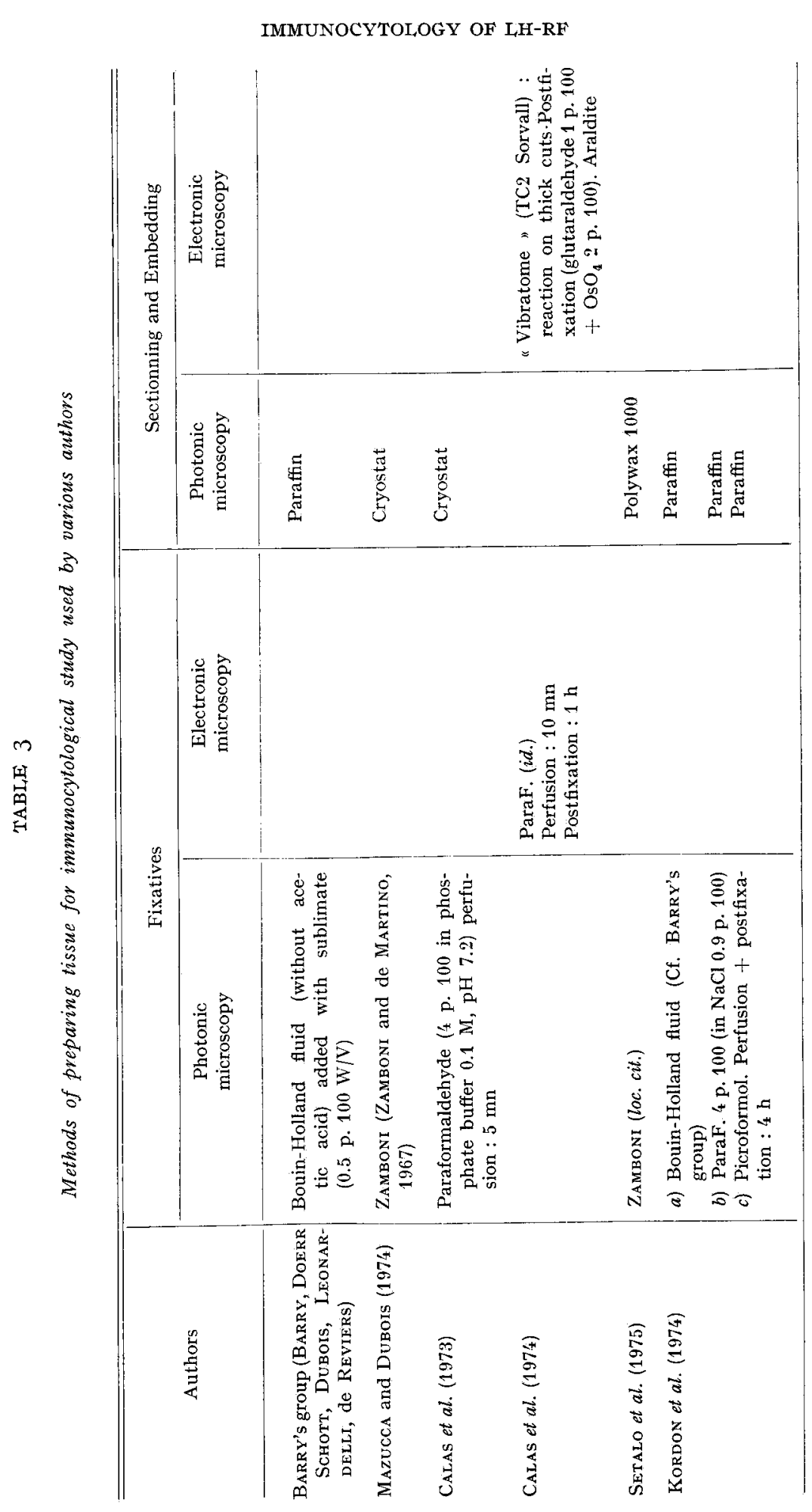




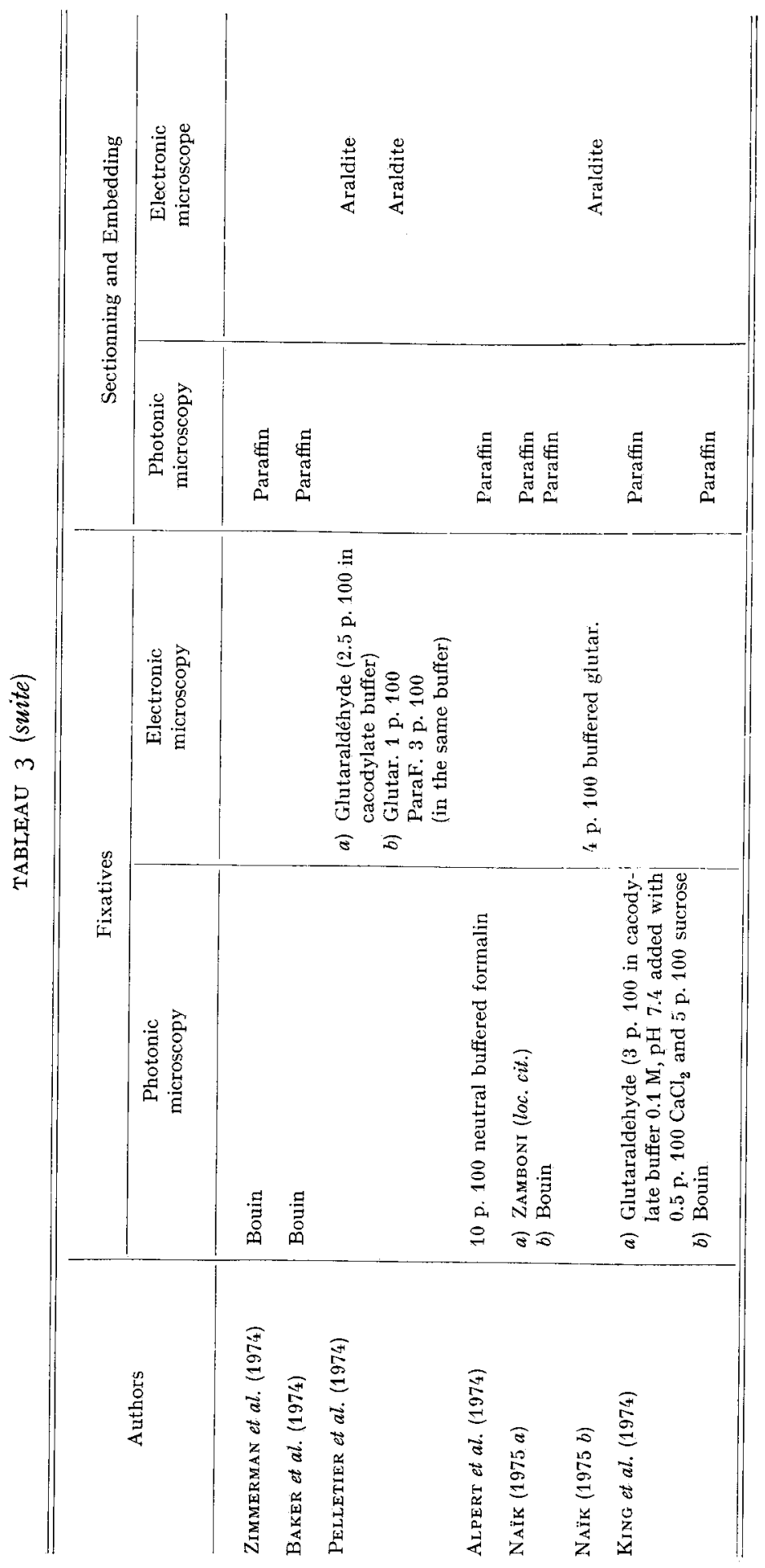


others fixed samples were cut into thick sections with "Vibratome ", stained with reactants, postfixed in osmic acid and embedded in araldite.

Table 3 shows the methods employed by various authors for preparing tissues.

\section{3. - Immunocytological staining}

In all cases, the indirect reaction was used (Goldman, 1968). Both methods, immunofluorescence and immunocytoenzymology, were used.

Using the later one, specific anti LH-RF Ab. was localized on antigenic structures of the preparations with sheep anti-rabbit IgG Ab linked with peroxydase either by covalence or by immunological binding (immunoglobulin-enzyme bridge technique of MASON et al., 1969), or with soluble rabbit [antiperoxydase-peroxydase] complex according to STERNBERGER et al., I970.

As a general rule, the substrate used in these immunochemical tests was diaminobenzidine, with or without osmic acid poststaining.

\section{RESULTS}

There is a general agreement in the localization of LH-RF axons and axonal endings but fundamental divergencies concern the localization of LH-RF neuronal pericaryons.

\section{I. - Axonal ways}

In guinea-pig, most of the axons coming from the LH-RF-producing cells are incorporated in a preoptico infundibular neurosecretory tract (BARRY, loc. cit.). These axons terminate in close contact with the capillaries of the primary portal plexus by means of long radiating collaterals.

Some axons (or collaterals of axons) form accessory extra hypophyseal neurosecretory pathways : immunoreactive axons may be seen in various parts of the hypothalamus, epithalamus, telencephalon and mesencephalon, particularly in the supraoptic crest, the vascular organ of the lamina terminalis (less developed and smaller in guinea-pig than in rat), the amygdalic complex, the supramammillary area and the capsule of the mammillary body, beyond the terminal part of the anterior crura of the fornix, in the floor of the mesencephalodiencephalic junction, as far as the epithalamoepiphyseal area, beyond the subcommissural organ and near the habenula.

It seems that the axons terminate in the area of the supraoptic crest, in the vascular organ of the lamina terminalis and in the epithalamoepiphyseal area. These immunoreactive axons probably play a very important role in intersegmental regulations; these mechanisms remain to be studied. The morphological substrate for these activities seems to be " neurosecretory synapses " recalling the arrangements already described for the extrahypophyseal Gomori $\oplus$ neurosecretory pathways (LEGAIT and LEGAIT, cit. by BARRY, I96r).

Some of these synapses appear to be of axosomatic type. Physiologically, their role might be to inform certain centers of the state of activity of LH-RF producing neurons.

Stereotaxic lesions performed at different levels show typical accumulation 
of intraaxonal immunoreactive material above the lesion. This accumulation is less spectacular than that seen after stereotaxic interruption of cathecholaminergic and serotoninergic axons.

Immunoreactive L.H-RF is already seen in the dorsal labium of the M.E. of 45 day guinea-pig foetus. The amount increases up to term, decreases immediately after birth and increases again a week or two later.

In adult female, after puerperium and before the first post-partum ovulation, considerable depletion of fluorescent material can be seen.

During the first post-partum cycle and in cyclic females, significant modifications can be observed in the quantity of specifically immunoreactive material along the distal part of the " preoptico infundibular LH-RF neurosecretory pathway ". A sudden drop to minimum concentrations occurs during prooestrus and preovulatory period of oestrus followed by a progressive increase during post-ovulatory period of oestrus and postoestrus. A minimum concentration occurs towards the end of dioestrus with some individual variations.

2. In rats and mice, there is less $L_{1} H-R F$ than in guinea-pig. In rat, the stain forms a crown around and above the peripheral portion of the pars tuberalis and the part lying between the infundibulum and the hypothalamus, and only occasionnally in other portions of the external layer of the M.E. In mice, LH-RF occurs in the peripheral region of the M.E. and is located along the proximal border of the external layer.

3. In sheep, swine and cattle, the axonal endings reach close to the pars tuberalis or the capillary loops of the intercalar plexus that penetrate into the M.E.

The ram is choice material for such a study because of quasi schematic LH-RF distribution (DUBoIs, I973 $a, b$ ) ; namely, the relation between the L.H-RF fibers and the palissadic layer of the M.E. seems different in this species when compared with guinea-pig or rat. On horizontal M.E. sections, the palissadic layer of the external area is localized at the posterior half of the M.E. and the upper part of the nervous pituitary stalk. In the anterior half, very dense LH-RF axonal endings terminate close to the pars tuberalis and come into contact with the small capillaries of the intercalar plexus. In the posterior half, where the palissadic layer is inserted between the pars tuberalis and the fibrous layer of the M.E. middle zone, the major part of the L,H-RF fibres remain in the fibrous layer, with dense axonal endings close to the capillary loops (short or long) of the portal plexus; only some of them perpendicularly enter the palissadic layer and insert themselves between its fibres to reach the small capillaries of the intercalar plexus placed at the precise border separating the pars tuberalis from the nervous tissue of the M.E.

4. In dog and cat (BARRY and DuboIs, I975), there is a well defined tubero infundibular tract passing by the dorsal labium of the M.E. ; some of its axons reach the nervous lobe of the pituitary gland. The preoptico infundibular tract is less dense ; its radiated collaterals electively end around the capillaries of the intercalar plexus but they stop at a distance from the long capillary loops.

5. In primates (BARRY et al., I975), reacting axonal fibres appear to constitute an hypothalamo or tubero infundibular tract; its periportal capillary endings are seen as radiated collaterals similar to those observed in different species (BARRY et al. I973; BARRY and DUBOIs, I973 a), but less numerous than in guinea-pig.

6. In birds, such as cock or duck, LH-RF fibres are plentiful in the external 
area of the M.E. ; they usually have a radial arrangement in the palissadic layer and a longitudinal one in the reticular layer. They terminate at the primary capillaries of the portal system and are scarce in the internal layer of the M.E.

7. In amphibians, LH-RF is dense in the M.E. of toad, but its distribution is unsystematic; LH-RF fibres in this species appear to reach the nervous lobe of the pituitary.

In the encephalon of Xenopus, the whole system of axons has been very well demonstrated from the pericaryons to the pituitary.

In the neotenic triton, axonal endings constitute a thin bundle arriving at the pituitary under the layer of ependymal cells that border the infundibular pouch.

\section{II. - Pericaryons}

I. ZIMMERMAN et al. (I974) thought to have demonstrated LH-RF in the pericaryons of certain cells of arcuate nucleus and ependymal tanycytes of the M.E. in mice ; their results were rejected as being unspecific by SETALo et al (1975) who failed, as did KoRDon et al. (I974), to find immunoreactive pericaryons in rat hypothalamus.

2. NAÏK (I975 $a, b)$ also reported he had localized immunoreactive LH-RH neurons (axons and pericaryons) in the hypothalamus at the microscopic as well as the ultrastructural level, in both rat and mice. According to this author, most of the neurons are scattered in the hypothalamus preoptic and medial prechiasmatic areas (where BARRy et al. (I973) found them in guinea-pig), ventro medial, arcuate nuclei and ventrolateral premamillary body. In our opinion, the pericaryon patterns given in the NAÏK's report were not sufficiently demonstrated : namely, the pictures of the arcuate nucleus resembled those that KorDon et al. (1974) found to be artefactual. At an ultrastructural level, while tlie pictures of immunoreactive axons in the M.F. seemed significative and agreed with results of PELLETIER et al. (loc. cit.) we were not convinced by the pictures showing a positive reaction (according to the author) in arcuate nucleus pericaryons.

3. Using our anti LH-RF antisera, on guinea-pigs, BARRY on one hand, LEONARDELII on the other, describe reacting pericaryons in various states:

a) in untreated guinea-pig foetus between days $5^{8}$ and 62 of gestation ;

b) in adult castrated males, given colchicine as an inhibitor of axoplasmic flow by the intracisternal way ;

c) in adult castrated males treated diversely : methanol or melatonine in methanolic solution in lateral ventricles ;

d) in normal animals given serotonin (at antiovulatory doses) by intraperitoneal or intracisternal ways. In this case, posterior LH-RF producing neurons cannot be seen, but anterior neurons are accumulating reacting material;

e) in animals given metaraminol or diethylthiocarbamate which decreases hypothalamic dopamine and noradrenaline; anterior LH-RF producing neurons are not affected whereas L,HRF increases in the posterior ones of the ventral tuber ;

$f$ ) sulpirid, an antiovulatory drug, augments the content of anterior neurons in LH-RF ; its action is blocked by catecholamine inhibitors ;

g) atropine also tends to increase the charge of $\mathrm{LH}-\mathrm{RH}$ producing neurons. 
Reacting pericaryons described by BARRY or by L,EONARDELLI in guinea pig are located in a large field, including the preoptic and the suprachiasmatic areas, surrounding the supraoptic recessus of the IIIrd ventricule, and reaching the dorsal and median septal nuclei in front and, behind, the caudal part of the tuber cinereum ; a few cells reach the premammillar area. This topography extends forward the hypophysiotropic zone of HaLASz in rat (SzENTAGotaI et al., I968).

According to these authors, these cells compose three groups : a principal one in the prechiasmatic and suprachiasmatic areas; a pre and pericommissural group, and a third group in front at a distance from the rostral commissura. The cells have a diameter of $20-25 \mu$ and they are ovoïd or pyriform in shape. They are usually scattered but may be found in small groups of 3 to 5 . Under the experimental conditions, the total number is not more than a few hundred per animal.

When the cells are stained by phenolic thionin after immunofluorescent detection, the pericaryons show a basophilic cytoplasm, a round vesicular nucleus ( $\varnothing$ 10-12 $\mu$ ) and very distinct centrally located nucleolus $(\varnothing 3 \mu)$.

4. As in guinea-pig, the prepuberal stage in dog and cat (BARRY and DUBors, I975, loc. cit.) favours the evidence of immunoreactive LH-RF neurons that does not need any experimental process for this purpose.

a) In cat, only a few pericaryons are usually conspicuous, whereas they are numerous in dog.

b) In this species, they are divided in two groups :

- in front in the preoptic and anterior hypothalamic areas and the septal and precommissural regions,

- in the rear side (about $40 \mathrm{p}$. Ioo of the whole) in the tuberal and premammillary zones. Some of these neurons may be seen in the periventromedian and dorsomedian areas and even in the rostral mesencephalic region (between the roots of the common ocular nerves or before the pedoncular ganglion).

The high percentage of immunoreactive pericaryons in the infundibular and premammillary regions agrees with the data related to the hypophysiotropic area (HALASZ et al., Ig62), the effects of surgical deconnexion of the mediobasal hypothalamus in rodents (HALASZ and GorskI, I967) and the persistence of infundibular immunoreactif LH-RF after a stereotaxic lesion in guinea pig (BARRY et al., I973).

According to the data suggesting a double mechanism for the hypothalamic control of pituitary gonadotropin secretion (BARRACLOUGH, I966), one could assume that the rostral group of LH-RF neurons in guinea-pig, cat and dog would regulate cyclic release of gonadotropins, whereas the posterior one (very evident in $\mathrm{dog}$ ) woued control basal (or tonic) secretion.

5. In primates (Cynomolgus, Cynocephalus, Cercopithecus, Papio and Macacus) in normal conditions, BARRY et al. (1975) observed most immunoreactive pericaryons electively localized in the mediobasal hypothalamic area (particularly in the infundibular nucleus and the premammillary zone, more rarely in the ventromedian and paraventricular areas).

So, the immunoreactive pericaryons producing L.H-RF have a very different topography : in primates, they chiefly are rostral though, in guinea-pig, they may be seen from the preoptic area (BARRY et al., r973) or even from the paraolfactive region (BARRY et al., I974). 
In this respect, the surgical deconnexion of the mediobasal hypothalamus produces very different results in rodents (HALASZ and GoRsKI, I967) as compared to primates (KNOBIL, I974) : the former maintain basal gonadotropins secretion but exhibit neither cyclic LH surge nor ovulation. On the contrary, in the latter, the isolated mediobasal hypothalamus is compatible with cyclic gonadotropins release and is able to assure the negative feed-back towards oestrogens.

This supposition agrees well with recent data showing the generality of oestrogenosensitive sites localized in the mediobasal hypothalamus of rhesus monkey (FERIN et al., I974). results.

6. Comparative endocrinology has put forward new arguments in favour of these

DOERR-SCHOTT and DUBOIs (I974), studying hypophysectomized toad, found a dense group of cells reacting with anti LH-RF Ab. These cells were localized in an accurate field next to the medioseptal nucleus in the posterior telencephalon. They were in the septum, behind the lateroseptal nucleus, and especially numerous at the posterior border of the telencephalic ventricles. The way the fibres led out from these cells indicated that they encountered the hypothalamo-hypophyseal tract (these fibres did not have the staining properties of the tract); they divided either next to the pars tuberalis or in the M.E.

Recently, these results were repeated by the same author on normal adult xenopus with a more demonstrative pattern of LH-RF neurons (pericaryons and axons).

\section{DISCUSSION}

As stated above, all the results from different groups concerning LH-RF axonal ways and endings are in good agreement. On the contrary, data are conflicting as regards the pericaryons.

I. SETALO et al. (1965) rejected the results of ZIMMERMAN et al. (I974) as not being specific : they observed staining of ependymal cells (as seen by ZIMMERMAN et al., on their material) with a non-specific serum (as purified rabbit IgG) as well as with anti LH-RF rabbit Ab. Similarly, BAKER et al. (I974) did not detect LH-RF in the ependyma of any of the three species investigated : rat, mouse or guinea-pig. We agree with these conclusions.

2. Above we criticized NAÏK's results in rat and mice (loc. cit.) ; no other author up to now has been able to demonstrate LH-RF pericaryons in these species in such conditions.

3. There is a strong opposition to BARRY and to LEONARDEI,I who identified immunoreactive cells chiefly in hypothalamus of guinea-pig. They are the only ones to study this along with other authors, principally using rats or mice (whose the demonstration of hypothalamic LH-RF neurons is not convincing). Neither BARRY's, LEONARDELLI'S, nor DOERR-SCHO'T''s results have been reproduced yet; but, no other workers used amphibians or tried to place guinea-pig in the same physiological or experimental conditions as BARRY or LEONARDELLI did in order to observe significant patterns of LH-RF neurosecretion in pericaryons.

There were two principal objections to their results : 
a) In questioning BARry's and LEONARDELLI's data, KORdon et al. (I974) argued from their own negative results in rat (BARRY and LEONARDELII were also unsuccessful in this species...) and from the evidence of many non specifically reacting cells and fibres in the arcuate nucleus, the septum and around the rostral commisura when they used antiguinea-pig antiglobulin. Thus, according to Kordon et al. (1974), the demonstration of fluorescent cells, as seen by BARRY and by LEONARDELLr, would be an artefactual reaction due either to a non specific adsorption of the reactants or to insufficiently saturated anti-HSA antibodies belonging to the anti LH-RF HSA antiserum used by BARRY and by LEONARDELII. Further more they critized the condition in which tissue was prepared for study by these authors (paradoxally, they did not contest the validity of results obtained in the same conditions by BARRY or LEONARDELLI in the M. E...).

This criticism is based only upon arguments drawn from their own failure and not on objective evidence :

- first, as regard the preparation of tissue for study, the evidence of results published in reports of BARRY and LEONARDELII cannot be denied nor can the excellent correspondance with similar data on LH-RF in M.E. from other authors (including those of Kordon et al...).

- Further more, neither BARRY nor other workers of this group ever used $\gamma$-globulin as a carrier for LH-RF to immunize antisera producing rabbits.

According to BARRY and our own experience, our anti LH-RF/HSA antisera or anti HSA Ab., used without HSA saturation, gave variable unreliable information which did not relate in any way to specific patterns found with anti LH-RF Ab. saturated by HSA or with complete absence of immunofluorescence using anti HSA Ab saturated by HSA. This is particularly true in the areas where KoRDoN et al., found non specific reacting cells with their own antiserum, chiefly in the area of the arcuate nucleus. Moreover, anti LH-RH/HSA Ab. saturated by HSA or anti HSA antisera were not able to reveal reacting cells or fibers in fields where anti LH-RF/HSA Ab. saturated by HSA did.

However, from our own experience, non specific fluorescent cells may have been seen [with anti (LH-RF/HSA) Ab. saturated by HSA] in some parts of ovine, bovine or porcine encephalon, but this fuorescence has never been inhibited when the antibody was saturated by $L H-R F$, so that immunoreactive fibers of the M.E. were not evident.

On the contrary, reactions observed by BARRY or by LEONARDELLI and given as being specific on their material became negative after saturation by the LH-RF of the antiserum they used (after previous neutralisation of anti HSA Ab.).

- Using anti LH-RF antisera prepared by KERDELHUE, BARRY repeated the same trials in guinea-pig (per. comm.) and did not observe aspecific reactions with his usual method as KORDoN et al., did.

b) As regards the antigen we used to obtain anti LH-RF antisera (binding of LH-RF decapeptide with HSA by gluteraldehyde or toluene diisocyanate), SETALO et al. (I975) questioned the specificity of our antibodies, because the LH-RF decapeptide lacks a reactive free amino group that would be necessary for such conjugations.

Moreover, the purity of our LH-RF preparation not having been given in our reports, they thought « ... it is possible that some impurities of breakdown products of $\mathrm{L}, \mathrm{H}-\mathrm{RF}$ with free aminogroups could have been coupled with the carrier protein : 
in such a case, the antibody would have been induced against such a product ... ".

As concerns the second point, table 4 gives the characteristics of the product we used.

\section{TABLE 4}

Biochemical characterisation of $L H-R F$

\begin{tabular}{|c|c|c|c|}
\hline \multicolumn{4}{|l|}{ I. - Aminoacid analysis } \\
\hline $\begin{array}{l}\text { Serine } \ldots \ldots \ldots \\
p \text {-Glutamic } \ldots \ldots \\
\text { Proline } \ldots \ldots \ldots \\
\text { Glycine } \ldots \ldots \ldots \\
\text { Leucine } \ldots \ldots \ldots \\
\text { Tyrosine } \ldots \ldots \ldots \\
\text { Histidine } \ldots \ldots \\
\text { Arginine } \ldots \ldots \\
\end{array}$ & $\begin{array}{l}0.97 \\
1.06 \\
0.99 \\
2.12 \\
1.02 \\
0.87 \\
1.02 \\
0.97\end{array}$ & $\begin{array}{l}\text { Short column run } \\
\text { Tryptophan } \ldots \ldots \\
\text { Histidine } \ldots \ldots \\
\text { Arginine } \ldots \ldots\end{array}$ & $\begin{array}{l}1.16 \\
0.93 \\
0.91\end{array}$ \\
\hline \multicolumn{4}{|c|}{$\begin{array}{l}\text { (Stimulation in vivo of } \mathrm{LH} \text { release by the sample : serum LH levels } \\
\text { measured by RIA were compared with those obtained from dose } \\
\text { of standard LH-RF). }\end{array}$} \\
\hline
\end{tabular}

(I) Dr. Schalley's Group : Veterans Administration Hospital, North Carolina.

In regards to the first point, HaBeEB and Hrramoto (I968) reported that, if glutaraldehyde preferably reacts with free amino groups (to $80-90 \mathrm{p}$. I0o), it also reacts with the imidazol ring of histidine $(30-40 \mathrm{p}$. IOO) and the phenolic ring of tyrosine (20 p. IOo) when tyrosine is linked with glycine; such a condition is met by LH-RF ( $\mathrm{C}_{2}$-histidine, $\mathrm{C}_{5}$-tyrosine- $\mathrm{C}_{6}$-glycine). In our tests, ${ }^{125} \mathrm{I}-\mathrm{L} / \mathrm{H}-\mathrm{RF}$ was incorporated at a $23 \mathrm{p}$. Ioo level.

SchIck and SiNGER (I96I), using toluene diisocyanate, called up the reactions of the isocyanate group as well with $(\mathrm{OH})^{-}$as with $\left(-\mathrm{NH}^{2}\right)$ : serine with its primary alcool group and the phenol $(\mathrm{OH})$ of tyrosin may be related to this type of conjugation In our tests, ${ }^{125}$ I-LH-RF was incorporated at a $30 \mathrm{p}$. roo level.

\section{CONCLUSION}

Determination of the chemical formula of LH-RF (MATSUo et al., I97I ; SCHALIY et al., I97I ; SIEVERTSSON et al., I97I) and its synthesis have made possible the preparation of specific antibodies. By the use of these, the hypothalamic structures involved in the synthesis, transport and transfer (to blood or cerebrospinal fluid) of $\mathrm{L}$ H-RF can be demonstrated by immunofluorescence or by cytoimmunoenzymology. 
The presence of axons carrying LH-RF, particularly in the distal regions of the hypothalamus, can easily be shown in vertebrates (with the exception of reptiles and fish). However, vizualization of specifically immunoreactive perykaria raises many difficulties. Only in certain species, in particular physiological states and under favourable experimental conditions is it possible to observe reasonable numbers of specifically immunoreactive perykaria when proper controls are used.

The results presented are the work of a single school and therefore need confirmation. This work shows that the distribution of perykaria varies with the species. It is most marked in the mediobasal hypothalamus in the primates, but there are two groups of perykaria, anterior (in the septopreoptic area and anterior hypothalamus) and posterior (tubero-infundibular and premamillary) in the guinea-pig, dog and cat, whereas they are concentrated in the posterior septal zone in Xenopus and the common toad.

These different distributions correspond, at least in rodents and primates, with the differences observed after surgical deafferentation of the mediobasal hypothalamus in these animals (HALASz and GoRski, I967 ; KNOBIL, I974).

In the guinea-pig, dog and cat, the distribution corresponds to the hypophysiotrophic area of Halasz (HALASZ, PUPP and UhLARIK, I962) but extends beyond it, particularly anteriorly. In these species the division of perykaria into two groups of cells which react differently to pharmacological agents leads one to suppose, in conformity with the hypothesis of a double mode of control of the secretion of anterior hypophyseal gonadotrophin (BARRACLOUGH, I966), that the anterior group is involved in the cyclic discharge of gonadotrophins whereas the posterior group controls the basal or tonic secretion.

The completely different behaviour of the primate hypothalamus after mediobasal deafferentation agrees with the accumulation of LH-RH immunoreactive neurons and the oestrogen-sensitive sites in this region (KNOBIL, I974; FERIN et al., I974).

In the visualization of immunoreactive axons, immunocytology allows one to follow the effects of lesions of the LH-RF pathways after deafferentation of whole or part of the hypothalamus. It also demonstrates, in axosomatic synapses, unsuspected connections between the hypothalamus and various other parts of the brain. These links underline the neuromodulator role of LH-RF which is more than just the excretion of a gonadotrophin-releasing substance into the pituitary portal vessels.

The difficulties encountered in the visualization of perykaria synthesizing LH-RF in certain species, such as the rat, have yet to be explained. One must also question whether the immunohistochemical techniques used do not remove some of the neuropeptide from the structures which contain it. Perhaps a larger or smaller proportion of a free fraction (as opposed to a bound fraction probably occuring in cytoplasmic granules readily visible in nerve endings and therefore easily immobilized), varying in amount in different species, is lost at different times during the technical procedures used.

Perhaps there are also masked forms of LH-RF which are not susceptible to immunocytologic detection.

Further reseach is needed in order to define the topographical difference in the distribution of LH-RF neurons in the various classes and species of vertebrate and to explain these differences.

Symposium Gn-RH, Tours, 25 mars 1975. 


\title{
RÉSUMÉ
}

\author{
MISE EN ÉVIDENCE DU LH-RF DANS L'HYPOTHALAMUS \\ E'T L'ÉMINENCE MÉDIANE PAR IMMUNOCYTOLOGIE : REVUE
}

I. Après un historique des travaux consacrés à la détection immunocytologique du LH-RF, sont exposées les conditions d'obtention des antisérums utilisés par les différents groupes de recherches, les espèces étudiées, les modalités techniques de la réaction immunocytologique en microscopie photonique et électronique selon les différents auteurs.

2. Les résultats séparent ce qui a trait à la mise en évidence des fibres nerveuses à LH-RF et des extrémités axonales d'une part, des péricaryons d'autre part.

A. - En ce qui concerne le premier point, les résultats présentés par les différents auteurs sont dans l'ensemble concordants.

a) La voie neurosecrétrice preoptico-infundibulaire à $\mathrm{LH}-\mathrm{RF}$ du cobaye a été bien étudiée par BARRY et al., ainsi que les voies accessoires extrahypophysaires, s'achevant principalement au niveau de la crête supraoptique, de l'organe vasculaire de la lame terminale et de l'aire épithalamoépiphysaire. Les variations physiologiques de la charge en LH-RF de l'éminence médiane (E.M.) où s'achève la majorité des fibres à LH-RF sont exposées.

b) Dans 1'E.M. du Rat et de la Souris, l'accumulation de LH-RF est relativement moins importante.

c) La répartition de LH-RF dans l'E.M. du Bélier a été étudiée plus spécialement par l'auteur qui en précise la disposition quasi schématique : le LH-RF s'accumule au contact direct des capillaires du plexus intercalaire jouxtant la pars tuberalis hypophysaire dans la partie rostrale de l'E.M., mais au niveau de la partie caudale, il n'atteint ceux-ci que par l'intermédiaire de fibres perpendiculaires espacées traversant la couche palissadique de la zone interne ou s'accumule autour des anses courtes et longues de ce même plexus.

d) La distribution des fibres et extrémités axonales à LH-RF chez le Chien, le Chat, les primates, les oiseaux (coq, canard), les amphibiens (crapaud, xénope, triton) est mentionnée.

B. - La mise en évidence des péricaryons aboutit à des résultats contestés.

a) Chez la Souris, les résultats de Zimmerman et al. (1974) sont rejetés comme dénués de spécificité ;

b) ceux de NAÏK (1975) chez le Rat et la Souris apparaissent non convaincants ;

c) les résultats obtenus par le groupe de Barry et Leonardelli chez le Cobaye, le Chien, le Chat et les primates et par DoerR-Schott sur les amphibiens n'ont pas encore été confirmés. Pour ces auteurs, la répartition des pericaryons apparaît variable selon les espèces : dans l'hypothalamus médiobasal chez les primates, séparés en deux groupes, antérieurs et postérieurs, au sein d'une zone allant de l'aire préoptique à l'extrémité caudale du tuber cinereum chez le Cobaye, le Chien et le Chat, au niveau des noyaux postérieurs du septum chez le Crapaud et le Xénope. Ces résultats obtenus chez les mammifères s'accordent avec ceux tirés de la déconnexion chirurgicale de l'hypothalamus médiobasal dans ces mêmes espèces.

Les critiques opposées à cette identification des péricaryons synthétisant le LH-RF sont discutées.

Enfin, l'existence d'un LH-RF " libre " ou " masqué " s'opposant au LH-RF " lié " est évoquée pour expliquer les difficultés éprouvées dans la mise en évidence du décapeptide chez certaines espèces, dont le Rat.

\section{REFERENCES}

Alpert C. C., Brawer J. R., Jackson I. M. D., Patel Y., i975. Somatostatin and LIRH : immunohistochemical evidence for distinct hypothalamic distribution. Fed. Proc., 34, 239 (Abst. II4).

Arimura A., Sato H., Kumasaka T., Worobec R. B., Debeljuk L., Dunn J., Schally A. V., 1973. Production of antiserum to $\mathrm{LH}-\mathrm{RH}$ associated with gonadal atrophy in rabbits : development of radioimmunoassay for LH-RH. Endocrinology, 93, 1092-I 103. 
Arimura A., Sato H., Cox D. H., Worobec R. B., Schally A. V., Yanaihara N., Hashimoto $T_{\text {, }}$ Yanaihara $\mathrm{C}$., Sujura N., 1975. The antigenic determinant of the LH-RH for three different antisera. Acta endocrinol. (Kbh) 78, 222-23I.

Baker B. L., Dermody W. C., ReEL J. R., 1974. Localization of LH-RH in the mammalian hypothalamus. Amer. J. Anat., 139, I29-134.

Barraclough C. A., I966. Modification of the CNS regulation after exposure of prepuberal rats to steroïd hormones. Rec. Prog. Horm. Res., 22, 503-536.

Barry J., r96r. Recherches morphologiques et expérimentales sur la glande diencéphalique de l'appareil hypothalamo-hypophysaire. Ann. Sci. Univ. Besançon (2 e ser., zoologie-physiologie, fasc., I5).

BARRY J., DUboIs M. P., I973a. Étude en immunofuorescence des structures hypothalamiques à compétence gonadotrope. Ann. Endocr., 34, 735-742.

Barry J., Dubois M. P., I973 $b$. La voie neurosécrétrice préoptico infundibulaire à LH-RF chez le Cobaye au cours de la gestation. C. R. Soc. Biol., 167, 1812-1815.

BARRY J., DuboIS M. P., I974 $a$. Study of the preoptico infundibular LH-RH neuro-secretory pahtway in female guinea-pig during gestation and the oestrous cycle. In Neurosecretion. The final neuroendocrine pathreay, Knowles F. and Volratr L. Ed, Springer Verlag, Berlin, Heidelberg, N. Y., I 48 -I 53 .

Barry J., Dubois M. P., I974 b. Étude en immunofluorescence de la différenciation prénatale des cellules hypothalamiques élaboratrices de LH-RF et de la maturation de la voie neurosécrétrice proptico-infundibulaire chez le Cobaye. Brain Res., 67, 103-113.

Barry J., Dubors M. P., $1974 \mathrm{c}$. Différenciation périnatale du contrôle hypothalamique de la sécrétion des gonadotrophines chez les mammifères. In : Colloque international sur l'endocrinologie sexuelle de la période périnatale, Forest M. G, and Bertrand J. Ed., I.N.S.E.R.M., 32, 63-78.

BARRY J., DUBoIs M. P., I974 d. Immunofluorescence study of the preoptico-infundibular LH-RH neurosecretion pathway of the guinea-pig during the oestrous cycle. Neuroendocrinology, 15, 200-208.

BARRY J., Dubois M. P., 1974 e. I a voie préoptico-infundibulaire à LRF chez les mammifères. Bull. Assoc. Anat., 58, 245-250.

BarRy J., Dubois M. P., I974 $f$. Histophysiologie de la voie neurosécrétrice préoptico-infundibulaire à LH-RH chez le Cobaye. Ann. Endocr. (Paris), 35, 573-574.

Barry J., Dubois M. P., I975. Étude comparée en immunofluorescence des neurones élaboratrices de LRF chez les mammifères. Arch. Anat. Microsc., (sous presse).

BARRY J., Dubois M. P., Poulain P., I973. LRF producing cells of the mammalian hypothalamus. A fluorescent antibody study. Z. Zellforsch., 146, 35 I-366.

Barry J., Dubois M. P., Poulain P., Leonardelli J., I973. Caractérisation et topographie des neurones hypothalamiques immunoréactifs avec des anticorps anti LH-RF de synthèse. $C$. R. Acad. Sc., Paris, Ser. D, 276, 319r-3193.

Barry J., Dubois M. P., Carette B., I974. Immunofluorescent study of the preoptico-infundibular LRF neurosecretion pathway in normal, castrated or testosterone-treated male guinea-pig. Endocrinology, 95, I4I6-I423.

Barry J., Girod C., Dubors M. P., 1975. Topographie des neurones élaborateurs de LRF chez les primates. Bull. Assoc. Anat., 59, 103-1 ro.

Calas A., Kerdeliue B., Assenmacher I., Jutisz M., ig73. Les axones à LH-RH de l'éminence médiane. Mise en évidence chez le Canard par une technique immunocytochimique. $C . R$. Acad. Sc., Paris, Serv D, 177, I765-2768.

Calas A., Kerdelhue B., Assenmacher I., Jurisz M., 1974. Les axones à LH-RF de l'éminence médiare. Étude ultrastructurale clıez le Canard par une technique immunocytochimique. $C$. $R, A c a d$. Sc., Paris, Ser. D, 278, $2557-2559$.

Dermody W. C., Becvar E. A., Windsor B. L., Reel J. R., I973. A radioimmunoassay for LHRF. Fed. Proc., 32, 239.

Doerr-Schot J., Dubois M. P., I974. Fixation de l'anticorps anti LH-RH au niveau de la neurohypophyse de crapaud Bufo vulgaris Laur. C. R. Acad., Sc., Paris, Ser. D, 278, 1397-1 399.

DoerR-Schotr J., Dubois M. P., I975a. Localisation et identification d'un centre LH-RF dans l'encéphale de crapaud. Bufo vulgaris Laur. C. R. Acad. Sci., Paris, Ser. D, 280, I 285-1 287.

Doerr-SchotT J., Dubors M. P., r975 b. Imm nnocytological localization of LH-RF neurons in Xenopus Laevis. VIIIth Conf. Europ. Compar. Endocrinol, Bangor (Submitted to be published). (Abstr.).

Dubors M. P., I973a. Localisation by immunoffuorescence of LH-RH in the nervous structure of the ram, boar and bull. J. Reprod. Fert., 35, 595 .

Dubors M. P., r973 b. Communication for the Symposium of the French Society of Experimental Endocrinology, Marseille.

Dubois M. P., BARRY J., I974. Répartition comparée des trois neurofacteurs hypothalamiques : I.H-RF, SRIF et neurophysine dans l'hypothalamus et l'éminence médiane : étude en immunofluorescence. Ann. Endocr., 35, 663-664. 
Ferin M., Carmel P. W., Zimmerman E. A., Warren M., Perez R. L., Van de Wiele R., I974. Location of intra hypothalamic oestrogen-responsive sites influencing LH secretion in the female Rhesus monkey. Endocrinology, 95, 1059-1068.

Goldman M., I968. In Fluorescent antibody methods, Acad. Press, N. Y., I57-I60.

Halasz B., Pupp C., Uhlarik S., 1962. Hypophysiotrophic area in the hypothalamus. J. Endocr. 25, I $47-154$.

Halasz B., Gorski R. A., 1967. Gonadotrophic hormone secretion in female rats after partial or total interruption of neural afferents to the medial basal hypothalamus. Endocrinology, 80, 608-622.

Habeeb A. F. S. A., Hiramoto R., I968. Reaction of protein with glutaraldehyde. Arch. Biochem. Biophys., 126, 16-26.

Kerdelhue B., Jutisz M., Gillessen D., Studer R. O., 1973. Obtention of antisera against a hypothalamic decapaptide (LH-FSH/RF) which stimulates the release of pituitary gonadotrophins and development of its radioimmunoassay. Biochem. Biophys. Acta, 297, 540-548.

King J. C., Parsons J. A., Erlandsen S. L., Williams T. H., I974. LH-RF pathway of the hypothalamus revealed by the unlabelled antibody peroxidase-antiperoxidase method. Cell Tiss. Res., 153, $21 \mathrm{I}-218$.

KNobit, E., 1974. On the control of gonadotropin secretions in the rhesus monkey. Rec. Prog. Horm. Res, , 80, I-46.

Kordon C., Kerdelhue B., Pattou E., Jutisz M., I974. Immunocytochemical localization of LH-RH in axons and nerve terminals of the rat median eminence. Proc. Soc. Exp. Biol. Med., 147, 1 22I27.

Leonardelli J., Barry J., Dubois M. P., 1973. Mise en évidence pai immunofluorescence d'un constituant immunologiquement apparenté au LH-RF dans l'hypothalamus et l'éminence médiane chez les mammifères. C. R. Acad. Sc., Paris, Ser. D, 276, 2043-2046.

Leonardelli J., Dubois M. P., r974a. Neurotransmetteurs hypothalamiques et centre élaborateur de LH-RH. Bull. Assoc. Anxt., 58 (162), 599-61o.

Leonardelli J., Dubois M. P., I974 $b$. Commande aminergique et cholinergique des cellules hypothalamiques élaboratrices de LH-RF chez le Cobaye. Ann. Endocr., 35, 639-648.

Leonardelli J., Dubois M. P., Poulain P., 1974. Effect of exogenous serotonin on LH-RH secreting neurons in the guinea-pig hypothalamus as revealed by immunofluorescence. Neuroendocrinology, $15,69-72$.

Mason T. E., Phifer R. F., Spicer S. S., Swallow R. A., Dreskin R. B., 1969. An immunoglobulin-enzyme bridge method for localizing tissue antigens. J. Histochem. Cytochem., 17, 563-569.

Matsuo H., Baba Y., Nair R. M. G., Arimura A., Schally A. V., I97i. Structure of porcine LH and FSH-releasing hormone. I. Proposed aminoacid sequence. Biochem. Biophys. Res. Commun., 43, I 334-1 339 .

Mazucca M., Debois M. P., I974. Detection of LH-RH in the guinea-pig median eminence with an immunohistoenzymatic technique. J. Histochem. Cytochem., 22, 993-995.

Moriarty G. C., Halmi N. S., I972. Electron microscopic study of the ACTH producing cell with the use of unlabelled antibody and the soluble peroxidaseantiperoxidase complex. J. Histochem. Cytochem., 20, 590-603.

NAïK D. V., $1975 a$. Immunoreactive LH-RH neurons in the hypothalamus identified by light and fluorescent microscopy. Cell Tiss. Res., 157, 423-436.

NAïk D. V., I975 b. Immunoelectron microscopic localization of LH-RH in the arcuate nuclei and median eminence of the rat. Cell Tiss. Res., 15\%, 437-455.

Nett T. M., Akbar A. M., Niswender G. D., Hedlung M. T., White W. F., I973. A radioimmunoassay for gonadotropin-releasing hormone (Gn-RH) in serum. J. Clin. Endocrinol. Metab., 36, 880-885.

Pelletier G., Labrie F., Puviani R., Arimura A., Schally A. V., 1974. Immunohistochemical localization of LH-RH in the rat median eminence. Endocrinology, 95, 314-317.

de Reviers M., Dubois M. P., r974. Binding of synthetic LH-RF antibodies in the median eminence of the cockerel. Horm. Metab. Res., 6, 94 .

Schally A. V., Arimura A., Kastin A. J., Baba N., Reeding T. W'., Nair R. M. G., DebelJUK L., I97I. Gonadotropin releasing hormones: one polypeptide regulates secretion of LH and FSH. Science (Wash.), 173, 1036-1037.

Setalo G., Vigh S., Schally A. V., Arimura A., Flerko B., 1975. LH-RH containing neural elements in the rat hypothalamus. Endocrinology, 96, 135-142.

Shick A. F., Singer S. J., I96I. On the formation of covalent linkages between two protein molecules. J. Biol. Chem., 236, $2477-2485$.

Sievertsson H., Chang J. K., Currie B. L., Bogentoft L., Folkers K., Bowers C. Y., I97I. On the structure of the luteinizing hormone releasing hormone (LRH) and the specificity of activity of LRH and the thyrotropin releasing hormone (TRH). Fed. Proc., 30, I I93-II95.

Sternberger L. A., Hardy P. H. Jr., Cuculis J. J., Meyer H. G., i9\%o. The unlabelled antibody enzyme method of immunochemistry. Preparation and properties of soluble antigen-antibody complex (horseradish peroxidase, anti horse radish peroxidase) and its use in identification of spirochetes. J. Histochem. Cytochem., 18, 3 I 5-333. 
Szenthgotilat J., Flerko B., Mess B., Halasz B., I968. Hypothalamic control of the anterior pituitary. An experimental-morphological study. Akademiai Kiado, Budapest, i 18-155.

Zamboni L., De Martino C., I967. Buffered picric acid formaldehyde : a new rapid fixation for electron microscopy. J. Cell. Biol., 35, I48 A.

Zimmerman E. A., Hsu K. C., Ferin M., Kozlowsky G. P., 1974. Localization of gonadotropinreleasing hormone (Gn-RH) in the hypothalamus of the mouse by immunoperoxydase technique. Endocrinology, 95, I-8.

\section{Abbreviations}

ME : Median eminence

PT : Pars tuberalis

$\mathrm{PL}$ : Palissadic layer

DL : M.E. dorsal labium

VL : M.E. ventral labium

SCL : Short capillary loop

$\mathrm{CV}$ : Capillary vessel

LV : Lateral ventricle.

\section{PLATE I}

Ram. Median Eminence. Parasagittal plane (Immunofluorescence ; poststaining by Evans Blue)

Strong heaping up of LH-RF axonal endings (arrows) close to pars tuberalis in rostral pars of dorsal and ventral labia, in front of the anterior limit of the palissadic layer (Mag. $\times 250)$. 


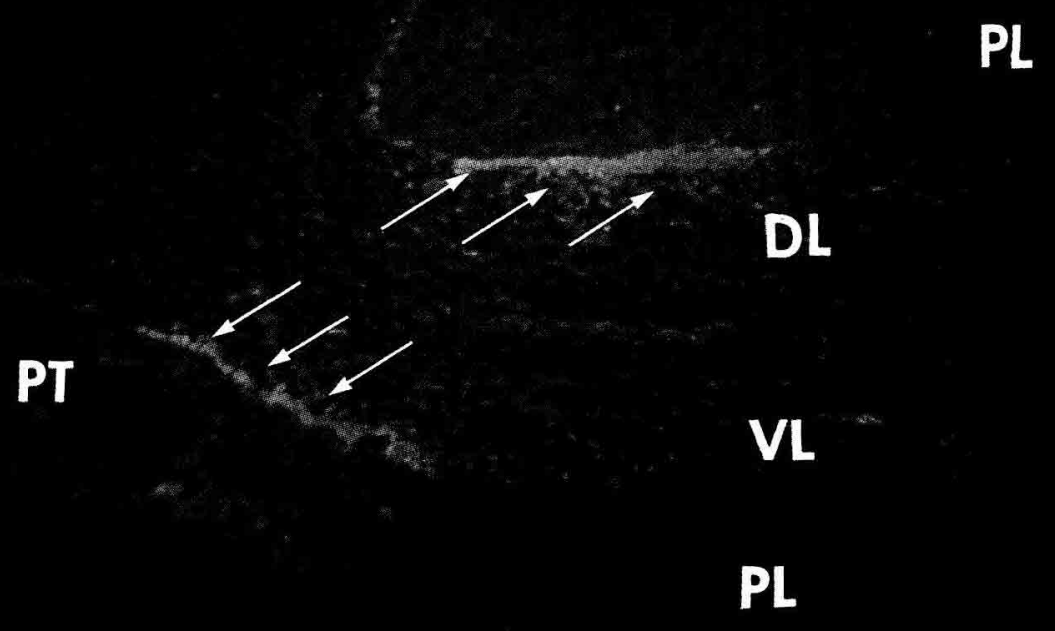




\section{PLATE II}

Above : Ram. M.E. horizontal section (immunofluorescence).

Strong accumulation of LH-RF axonal endings in M.E. rostral pars, close to pars tuberalis (in this region, palissadic layer is absent) (Mag. $\times 250$ ).

Below : Ram. M.E. frontal section (immunofluorescence)

In palissadic layer LH-RF axons end at a short capillary loop and small capillary vessels (arrows) of intercalar plexus (at the junction separating M.E. from pars tuberalis). Only a few fibres cross palissadic layer (compare with the upper figure) (Mag. $\times 1000$ ). 

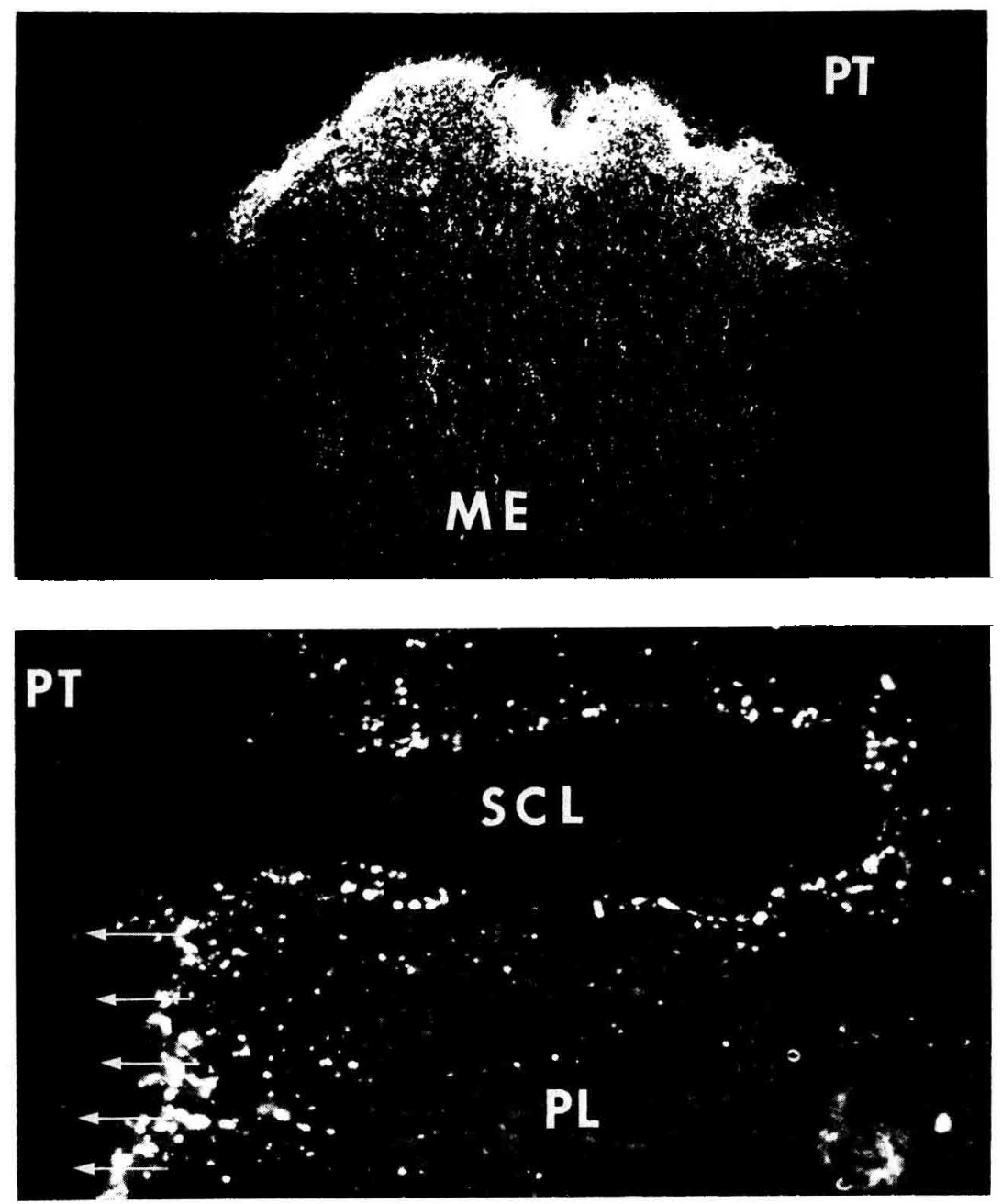
PLATE III

Above : Cock. $M$ E. (Immunofluorescence).

LH-RF axons and axonal endings (de Revizns \& Dubois) (Mag. $\times 250)$.

Below : Hypophysectomized buffo. Telencephalon (Immunofluorescence).

Group of LH-RF perykaria (arrows) in the septum next to lateral yentricle (Mag. $\times 1.000$ ). (Courtesy of Dr. J. DoERRSchotT) 

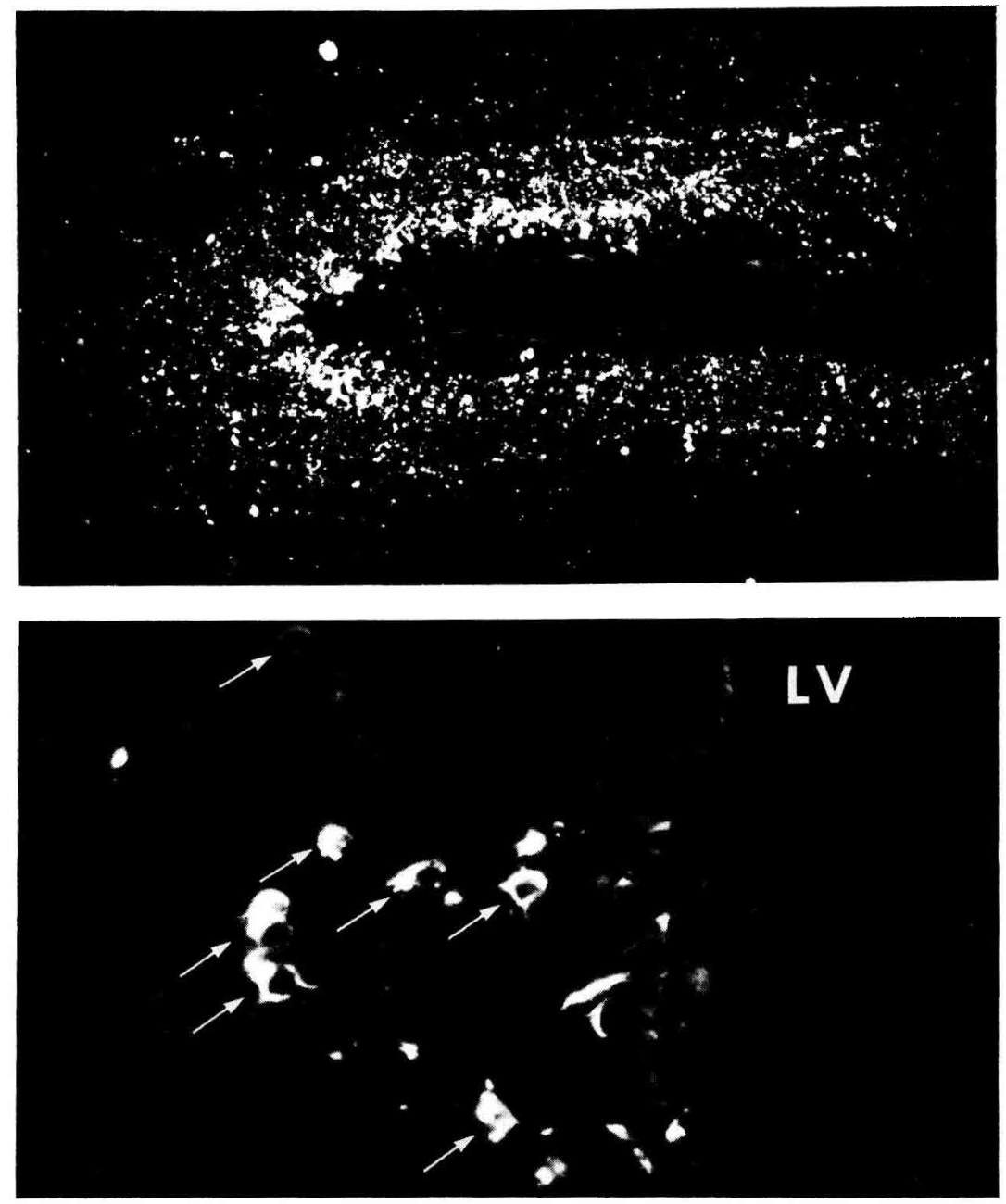

M. DUBOIS 